\title{
THE PROBATIVE VALUE OF POST-OFFENCE CONDUCT EVIDENCE
}

\author{
BC Naudé \\ Blur LLB LLD \\ Professor of Criminal and Procedural Law \\ University of South Africa (UNISA)
}

\begin{abstract}
SUMMARY
In certain circumstances, post-offence conduct can provide circumstantial evidence of guilt. It is, however, often difficult to state why a particular type of post-offence conduct makes guilt probable. The objective of this contribution is to identify principles that could assist in determining the probative value of certain types of postoffence circumstantial evidence. It is shown, with reference to specific types of postoffence conduct, that it is mostly speculative to make any inference from such evidence. In the end, it is submitted that the principles governing the assessment of circumstantial evidence will only allow an inference of guilt to be drawn from postoffence conduct if the inference was established beyond a reasonable doubt. It will not be enough to draw an inference from facts which were not, themselves, proved beyond a reasonable doubt, but which were merely accepted upon reasonable grounds.
\end{abstract}

\section{$1 \quad$ INTRODUCTION}

This article considers the extent to which post-offence conduct can provide probative circumstantial evidence of guilt. ${ }^{1}$ There are various types of postoffence conduct evidence or evidence of "after-the-fact" conduct that can possibly point towards the guilt of an accused. ${ }^{2}$ These types of conduct may conveniently be grouped into five categories: ${ }^{3}$ the accused may conceal the

This comment is based upon work supported financially by the National Research Foundation.

2 Mueller and Kirkpatrick Federal Evidence Vol 1 3ed (2011) 574 point out: "Behavior indicating a guilty mind encompasses a wide range of acts. Most importantly, the idea reaches flight from the scene or the jurisdiction, resisting arrest and false exculpatory statements, including use of an alias or false identification. Other behavior indicating guilty mind includes altering personal appearance, trying to escape or even trying to commit suicide, suborning perjury or fabricating evidence, destroying or concealing evidence, and killing, threatening, or impeding witnesses."

3 See generally Palmer "Guilt and the Consciousness of Guilt: The Use of Lies, Flight and Other 'Guilty Behaviour' in the Investigation and Prosecution of Crime" 199721 Melbourne University LR 95115 et seq. Often, however, it is the available options that make an accused choose a specific type of post-offence conduct. One can say that while the tactics may differ, the conduct shares a common feature. Mueller and Kirkpatrick Federal Evidence 582 note in this regard: "In each case the act suggests a guilty mind, and ultimately guilt of the crime charged." 
truth, for example, by lying or by tampering with evidence; the accused may refuse to assist with the investigation; the accused may fail to deny guilt; the accused may attempt to avoid apprehension and the accused may possibly show a guilty demeanour. Because perceptions based on demeanour are likely to depend upon highly subjective impressions which may be impossible to interpret, the probative value of such evidence will be equivocal. Therefore it may not be possible, for the most part, to eliminate innocent explanations for such behaviour, and this type of post-offence "conduct" will not be discussed here. ${ }^{4}$ The refusal of an accused to assist with an investigation and a failure to deny guilt will also not be considered. These types of post-offence conduct have constitutional implications that make it doubtful whether such evidence can be presented for the purpose of proving guilt. ${ }^{5}$

The problem with inferences from post-offence conduct is that these are often subject to "psychological generalizations"6 and it is hence difficult to say why a particular example of post-offence conduct makes guilt probable. ${ }^{7}$ This is where the problem lies: there are usually a number of inferences that can be drawn from post-offence conduct evidence. It could, for example, be possible that an accused might believe he or she is guilty of a crime other than the one under investigation and lie, not to conceal his or her involvement in the crime under investigation, but to conceal involvement in some other crime. ${ }^{8}$ Post-offence evidence would also have little probative value where the accused has admitted culpability in respect of more than one offence. In such an instance it would be very difficult to draw an inference of guilt with respect to one crime rather than the other. ${ }^{9}$ Post-

4 See Palmer 199721 Melbourne University LR 139 et seq for a discussion in this regard. See also Kaufman The Commission on Proceedings Involving Guy Paul Morin (1998) 11421150; Heath "Arresting and Convicting the Innocent: The Potential Role of an "Inappropriate" Emotional Display in the Accused" 200927 Behav Sci Law 313; and Simon "The Limited Diagnosticity of Criminal Trials" 201164 Vanderbilt LR 143.

5 See Palmer 199721 Melbourne University $L R 127-135$ in this regard. Also see $R v$ White [2011] 1 SCR 433 par 168. About this issue in the American context, see Hermann and Speer "Standing Mute at Arrest as Evidence of Guilt: The "Right to Silence" Under Attack" 200735 American Journal of Criminal Law 1. An accused who chooses not to testify during the trial must, however, bear the consequences of exercising his or her right to silence - see $S$ v Mavinini 2009 (1) SACR 523 (SCA) par 23; S v Tandwa 2008 (1) SACR 613 (SCA) par 53-56; and $S$ v Chabalala 2003 (1) SACR 134 (SCA) par 21.

6 Palmer 199721 Melbourne University LR 100. Mueller and Kirkpatrick Federal Evidence 574-575 point out: "An important point affecting all such proof is that it is universally considered insufficient, standing alone, to support a conviction, and doubts persist about probative worth."

7 See Boyle "First Rate' Fact Finding: Reasonable Inferences in Criminal Trials” 200858 Univ of New Brunswick LJ 199200.

8 Cf Palmer 199721 Melbourne University LR 106. Ignorance of the law or uncertainty about how it would be applied could possibly cause an innocent person to mistakenly believe themselves to be guilty of a crime and therefore cause them to act in a certain manner. A person might, for example, believe themselves to be guilty of murder or culpable homicide when in fact a ground of justification such as self-defence was available to them. See also the High Court of Australia's decision in Rv Woon (1964) 109 CLR 529 542-543.

9 See $R v$ White supra par 41. Rothstein J refers to $R v$ Arcangioli [1994] 1 SCR 129145 where Major J stated: "[W]here an accused's conduct may be equally explained by reference to consciousness of guilt of two or more offences, and where an accused has admitted culpability in respect of one or more of these offences, a trial judge should instruct a jury that such evidence has no probative value with respect to any particular offence." This argument can only apply where different crimes are involved - see the remarks made by the Victorian Supreme Court in $R v$ Woolley (1998) 42 A Crim R 418 423-424. 
offence conduct evidence might further have probative value as far as one fact in issue is concerned, but irrelevant as far as another fact is concerned. Evidence that an accused fled the scene of a crime, for example, might be relevant to show identity, but will usually be irrelevant in determining whether the accused had dolus or culpa and should therefore be convicted of murder or culpable homicide. ${ }^{10}$

Because a "second tier" of inferential reasoning is needed in instances where evidence of post-offence conduct is at issue, the requirements for the assessment of circumstantial evidence is the proper place to start looking for some perspective as far as the probative value of post-offence conduct evidence is concerned. ${ }^{11}$ In this comment it is submitted that the principles governing the assessment of circumstantial evidence will in most cases only allow an inference of guilt to be drawn from such evidence if the inference was established beyond a reasonable doubt. It will not be acceptable to draw an inference from facts which were not, themselves, proved beyond a reasonable doubt, but which were merely accepted upon reasonable grounds.

\section{THE ASSESSMENT OF CIRCUMSTANTIAL EVIDENCE: A BRIEF OVERVIEW}

In South Africa, the leading case dealing with the assessment of circumstantial evidence in criminal proceedings is $R v$ Blom. ${ }^{12}$ In this case it was said that before an inference could be drawn from circumstantial evidence the inference sought to be drawn must firstly be consistent with all the proved facts. If this is not the case, then the inference cannot be drawn. Secondly, the proved facts should be such that they exclude every reasonable inference that could be made from them save the one to be drawn. ${ }^{13}$ If all other reasonable inferences are not excluded, then there must be doubt as to whether the inference sought to be drawn is correct. ${ }^{14}$

It has been rightly pointed out that these rules "are not as clear in their meaning as they appear to be", and that they "raise more questions than they provide answers". ${ }^{15}$ A critical evaluation of these rules is far beyond the scope of this comment. As far as the first leg of the test is concerned, it has persuasively been argued that not all facts in a criminal trial have to be

10 See the discussion below.

1 See Zeffertt, Paizes and Skeen The South African Law of Evidence (2003) 93 for an explanation of the difference between normal evidence and circumstantial evidence.

121939 AD 188.

13 See $R$ v Blom supra 202-203.

14 See generally Schwikkard and Van der Merwe Principles of Evidence 3ed (2009) par 305 ; and Zeffertt, Paizes and Skeen The South African Law of Evidence 92. It is important that a court guard against seeing each piece of circumstantial evidence in isolation. A court should therefore consider the cumulative effect of all the pieces of circumstantial evidence - see Isaacs $v$ S [2010] 4 All SA 481 (SCA) par 61-62, where Navsa JA confirms this approach and refers to the Supreme Court of Appeal's decision in $S v$ Ntsele 1998 (2) SACR 178 (SCA) 182D-F.

15 See Zeffertt and Paizes Essential Evidence (2010) 24. See also Zeffertt, Paizes and Skeen The South African Law of Evidence 91 et seq. 
proved beyond a reasonable doubt, ${ }^{16}$ and as far as the second leg is concerned, it is clearly possible to draw an inference beyond a reasonable doubt "from intermediate facts that are not, themselves, proved beyond a reasonable doubt". ${ }^{17}$ If a fact, however, "is considered essential in the sense that proof of a particular element of liability will fail in its absence, the use of any standard of proof short of the criminal standard will necessarily be inadequate". ${ }^{18}$ When considering the assessment of circumstantial evidence in the form of post-offence conduct, a trier of fact should be especially cautious of making any inference from such evidence.

There have been a limited number of cases in South Africa that have dealt with the assessment of circumstantial evidence in the form of post-offence conduct by an accused. This has not been the case elsewhere and the issue has received a lot of attention in Canada and the USA. ${ }^{19}$ In these jurisdictions the probative value of such evidence is stated in terms of the

16 See generally the discussion by Zeffertt, Paizes and Skeen The South African Law of Evidence 94 et seq. In $R$ v Sibanda 1965 (4) SA 241 (RA) 246A-D Beadle J notes: "The degree of certainty with which the individual facts must be proved in criminal cases must always depend on the probative value of the individual facts themselves. Generally speaking, when a large number of facts, taken together, point to the guilt of an accused, it is not necessary that each fact should be taken in isolation and its existence proved beyond a reasonable doubt; it is sufficient if there are reasonable grounds for taking these facts into consideration and all the facts, taken together, prove the guilt of an accused beyond reasonable doubt. See $R \vee D e$ Villiers 1944 AD 493508 . Where there is, however, a particularly vital fact which in itself determines the guilt of an accused, it must be proved beyond reasonable doubt. Suppose, for example, the vital fact in determining the intent to kill in a murder case is whether or not the accused used a knife in killing the deceased. If the evidence merely showed that it was 'probable' that he used a knife, it could not be held against him in determining his guilt that he 'had' used a knife, because, unless there was proof 'beyond a reasonable doubt' that a knife was used, the accused's guilt could not be said to have been proved 'beyond reasonable doubt'." See also $R v$ Mtembu 1950 (1) SA 670 (A) 679-680.

17 Zeffertt, Paizes and Skeen The South African Law of Evidence 104. They explain the meaning of "an intermediate fact" (95) with reference to the second leg of the test in $R v$ Blom supra: "While it would serve us well in criminal cases in respect of those facts that have to be established beyond a reasonable doubt, the employment of a lesser standard of proof will often suffice in respect of proof of facts that are not part of the ultimate issues that the prosecution has to establish, facts that are sometimes referred to as 'intermediate facts' or 'primary facts' ... 'Primary facts', as the term suggests, are those facts which one selects as the starting points in the inferential chain. 'Intermediate' facts are all those facts that are neither primary facts nor ultimate facts." Mueller and Kirkpatrick Federal Evidence 557 provide more perspective: "Sometimes circumstantial evidence bears immediately on an element of a claim or defense, but the proof is fragmented and consists of many facts. Alone, each has little or no probative force, but the whole (the conjunction of all the facts) may almost impel a conclusion that some or all elements of a claim or defense have been shown. In such cases the proof can properly be viewed as a whole, and all various elements are relevant if the whole supports an inference on a point that matters in a case." In other instances circumstantial evidence provides background facts that give meaning to other evidence in a case that helps to appraise such evidence and assess the credibility of witnesses. Mueller and Kirkpatrick Federal Evidence 559 point out: "Circumstantial evidence that provides such background may be relevant if it throws other evidence into sharper relief, helps clarify or explain it, or makes it more vivid or real, as is true of demonstrative evidence, which has long been considered relevant."

18 Zeffertt, Paizes and Skeen The South African Law of Evidence 98.

19 Because a number of cases in South Africa have referred to the relevance of Canadian law for purposes of interpreting our law and since South Africa shares the same common law as far as the law of evidence is concerned with Canada and the USA, it is helpful to consider the way these systems approach problems as far as the assessment of post-offence circumstantial evidence is concerned. Reference has also been made to English, Australian and New Zealand cases. 
test for relevance. Once such evidence is admitted, not much seems to be able to affect the initial probative value of the evidence when the court assesses the evidence at the end of the case.

The following remarks made by Rothstein $\mathrm{J}$ in $R v$ White, on behalf of the majority of the Canadian Supreme Court, indicate the approach to the assessment of post-offence conduct as circumstantial evidence of guilt in Canada:

"The principle that after-the-fact conduct may constitute circumstantial evidence of guilt remains good law. At its heart, the question of whether such evidence is admissible is simply a matter of relevance ... As Major J. noted in White (1998), 'evidence of post-offence conduct is not fundamentally different from other kinds of circumstantial evidence. In some cases it may be highly incriminating, while in others it might play only a minor corroborative role' ... As with all other evidence, the relevance and probative value of post-offence conduct must be assessed on a case-by-case basis ... Consequently, the formulation of limiting instructions with respect to the broad category of postoffence conduct is goyerned by the same principles as for all other circumstantial evidence."

A similar approach is followed in the USA, where Federal Rule of Evidence 401 states that evidence is relevant if: "(a) it has any tendency to make a fact more or less probable than it would be without the evidence; and (b) the fact is of consequence in determining the action." ${ }^{21}$ This rule refers to direct or circumstantial evidence and can be described as setting a generous standard. Evidence will be relevant if it has any tendency to establish a fact of consequence. Graham ${ }^{22}$ explains that the use of the phrase "fact is of consequence" refers to the fact that "the breadth of admissibility of relevant evidence extends to facts not in dispute". Evidence will be relevant if it possesses any tendency to make a fact of consequence more or less probable than it would be without the evidence in the light of logic, experience, and accepted assumptions concerning human behaviour. ${ }^{23}$ He refers ${ }^{24}$ to Thayer $^{25}$ who pointed out that: "The law provides no test for relevancy". He further explains that the concept of relevance embodied in Federal Rule of Evidence 401 must be kept separate from

$20 R v$ White supra par 22. See also par 31, 36-38 and 40. Par 42 Rothstein $\mathrm{J}$ also remarks: "Thus, Arcangioli and White (1998) should be understood as a restatement, tailored to specific circumstances, of the established rule that circumstantial evidence must be relevant to the fact in issue. In any given case, the determination remains a fact-driven exercise. Whether or not a given instance of post-offence conduct has probative value with respect to the accused's level of culpability depends entirely on the specific nature of the conduct, its relationship to the record as a whole, and the issues at trial. There will undoubtedly be cases where, as a matter of logic and human experience, certain aspects of the accused's postoffence conduct support an inference regarding his level of culpability."

21 About the test for relevance in terms of American law, see generally Graham Handbook of Federal Evidence Vol 27 ed (2012) 472 et seq.

22 Graham Handbook of Federal Evidence 473.

23 See Graham Handbook of Federal Evidence 484. Gianelli Understanding Evidence (2003) 108 points out that: "Rule 401's standard does not require that the evidence make a consequential (material) fact 'more probable than not' (preponderance of evidence), but only that the material fact be more probable with the evidence than without the evidence." See also $R v$ Matthews 1960 (1) SA 752 (A) 758A-B, where Schreiner JA said that: "Relevance is based on a blend of logic and experience lying outside the law."

24 See Graham Handbook of Federal Evidence 486.

25 A Preliminary Treatise on Evidence at the Common Law (1898) 265. 
issues of sufficiency of evidence for any purpose such as to satisfy a burden of production. In this regard it has often been stated that "a brick is not a wall", referring to relevancy as the brick and sufficiency as the wall. Hence only minimal logical relevancy is required. Graham ${ }^{26}$ refers to New Jersey $v$ $T L O,{ }^{27}$ where the following was stated:

"But it is universally recognized that evidence, to be relevant to an inquiry, need not conclusively prove the ultimate fact in issue, but only have any tendency to make the existence of any fact that is of consequence to the determination of the action more probable or less probable than it would be without the evidence'."2

Although there are other Federal Rules of Evidence that are designed to limit the use of evidence that is concededly relevant, these limitations are not present in the case of circumstantial evidence, where Federal Rule of Evidence 401 operates essentially alone to set the basic relevancy standard. ${ }^{29}$ Mueller and Kirkpatrick note in this regard:

"The problem of circumstantial proof is to determine whether proffered evidence really does indirectly or inferentially support the point to be proved. Resolving this problem involves determining the purpose for which the proof is offered and formulating a general premise or evidential hypothesis that links the proof to the point to be proved. Often the hypothesis is left unstated, with little or no effort expended to assess relevancy.

The "evidential hypothesis" 31 they refer to contains one or more general premises (propositions of general knowledge about the ways of the world or human nature), along with at least one specific premise linking the proof to the general premises, and finally the conclusion towards which the evidence points. Mueller and Kirkpatrick point out ${ }^{32}$ that the probative value of circumstantial evidence "is a function of both the number and strength of the inferences in the evidential hypothesis that leads from the evidence to the point to be proved" ${ }^{33}$ In other words, it is about the strength of the evidential hypothesis and the factual basis or connection of the proof to the case. The relevance of post-offence conduct evidence will often depend on the type of post-offence conduct in question, but the same general principles should apply when considering the admissibility of the various kinds of post-offence conduct evidence that could possibly be indicative of guilt. For current

${ }^{26}$ Handbook of Federal Evidence 487.

27469 US 325 (1985) 345.

28 See also Mueller and Kirkpatrick Federal Evidence 568, noting that the term "fact is of consequence" includes various categories of proof. These categories are facts that are themselves elements of claims or defences; facts that support one or more inferences to elements in claims or defences and background facts (including facts that bear on the credibility of witnesses).

29 Mueller and Kirkpatrick Federal Evidence 541 et seq.

30 Mueller and Kirkpatrick Federal Evidence 542. They give the following definition of circumstantial evidence (551): "Circumstantial evidence means proof that does not actually assert or describe the point or proposition to be proved, but assert or describe something else, from which the trier may either reasonably infer the truth of the proposition (so the evidence is not only relevant but sufficient) or reasonably infer an increase in the probability that a proposition that matters in the case is true (so the evidence is relevant under Fed. $R$. Evid. 401 although not sufficient to prove it)."

31 See Mueller and Kirkpatrick Federal Evidence 562.

32 Federal Evidence 563-564.

${ }^{33}$ See Mueller and Kirkpatrick Federal Evidence 562-563. 
purposes only two types of post-offence conduct evidence will be considered, namely evidence of flight by the accused and evidence of lies by the accused.

\section{EVIDENCE THAT THE ACCUSED FLED FROM THE SCENE OF THE CRIME OR ATTEMPTED TO AVOID APPREHENSION}

In their discussion of American law on the topic of flight, Mueller and Kirkpatrick point out that circumstantial evidence involving flight usually invites four inferences: ${ }^{34}$

"First, the observed behaviour suggests flight. Second, flight suggests a guilty mind or conscience, which may mean nothing more than a desire to avoid detection (rather than any feelings of remorse or sense of wrongdoing). Third, consciousness of guilt suggests that the person is conscious of his involvement in the charged crime (as opposed to some other). Fourth and finally, consciousness of guilt for the charged crime suggests actual guilt of the charged crime."

Each of these inferences depends on its own evidential hypothesis. ${ }^{35}$ It can be said that first, someone who avoids contact with the police or distances himself from the scene in a way that is not the result of some innocent motive or explained in some innocent way is likely, or more likely than another, to be engaging in flight. The second inference depends on the hypothesis that someone who flees is likely, or more likely than another, to feel guilt. The third inference depends upon the hypothesis that someone who feels guilt shortly after a crime is committed is likely, or more likely than another, to feel guilt for involvement in that crime. The fourth inference depends on the premise that someone who feels guilty for involvement in a particular crime is likely, or more likely than another, to be actually guilty because he committed or was involved in that crime. The stated inferences and their associated hypotheses often present problems.

The first inference can be problematic because it may not be clear that the observed conduct amounted to flight, and hence the probative value of evidence suggesting flight will depend heavily on the circumstances of the case. ${ }^{36}$

The second inference presents the most difficulty. Mueller and Kirkpatrick ${ }^{37}$ point out that the logic or common experience that supports the premise is that those who are guilty have more reason to flee than those who are innocent. In other words, "an innocent person might have reason to flee, but a guilty person has at least one more reason". Even though it is possible to say that guilty persons are slightly more likely to flee than innocent persons, it is accepted that flight is "inherently ambiguous" and an inference of guilt from flight will always be doubtful. It is a fact that there "can

${ }^{34}$ Mueller and Kirkpatrick Federal Evidence 575. See more about these inferences in Clearly et al McCormick on Evidence 3ed (1984) 797-818; and Wigmore $A$ Treatise on the System of Evidence in Trial at Common Law (1904) par 265-293.

35 Mueller and Kirkpatrick Federal Evidence 575.

${ }^{36}$ See Mueller and Kirkpatrick Federal Evidence 576-577 for a discussion in this regard.

37 Federal Evidence 578. 
be a host of reasons why people may do stupid things after being involved in a traumatic experience". sense of panic, rather than to avoid apprehension. Flight may also take place to avoid getting arrested and becoming involved in a dysfunctional criminal-justice system where the jails are a dangerous place and where there is a strong possibility that the accused will be wrongly convicted of a crime of which he or she is in fact innocent. ${ }^{39}$ An accused may also flee to avoid the stigma associated with having been arrested or to avoid bail or parole being revoked where he or she has already committed other crimes. ${ }^{40}$ A desire to avoid inconvenience or legal expense or an aversion at having to implicate a friend is another possible reason.

The third inference (guilty mind relates to the crime charged), becomes problematic where there is also an indication that the conduct relates to some crime other than the crime charged. ${ }^{41}$ Where the accused has committed another offence, flight may indicate a guilty mind relating to that offence rather than the one charged. Something in the facts should indicate that a specific flight relates to the charged offence. If there are, for example, two offences and arrest and flight followed the second offence, the closer proximity of flight to the second offence could suggest that flight relates to it, but such evidence could still be ambiguous. It could also be shown that the accused knew he was being sought for the specific offence or that the charged offence is more serious or more likely to be on the mind of the accused. ${ }^{42}$

The fourth inference (guilty mind relating to charged crime means actual guilt of charged crime) is a strong inference to make, since a person is likely to know whether he committed a crime or not and is also likely to know whether there are any excuses for his or her conduct. Feelings of guilt do not, however, always say everything about the particular elements in the legal definition of guilt. ${ }^{43}$ Evidence that the accused fled the scene of a crime is a good example of a situation where evidence of post-offence conduct may have probative value as far as one fact in issue is concerned, but will be irrelevant as far as another is concerned. Evidence that an accused fled the scene of a crime might, for example, be relevant to show identity, but will usually be irrelevant in determining whether the accused had dolus or culpa and should therefore be convicted of murder or culpable homicide. In the same sense a lack of hesitation prior to flight should normally be irrelevant in determining dolus or culpa. In $R v$ White, however, the majority of the Canadian Supreme Court found that the fact that the accused failed to hesitate at the discharge of his firearm into the deceased's chest does potentially provide such information. ${ }^{44}$ In this case the accused and the deceased were engaged in a struggle when a handgun in the accused's possession was fired into the deceased's chest. The accused immediately fled the scene without any hesitation. The accused was subsequently

\footnotetext{
38 Per Hall JA in $R v$ Campbell (1998) 122 CCC (3d) 44 (BCCA) par 23.

39 See generally Palmer 199721 Melbourne University LR 136 et seq.

40 See the South Australian case of $R v$ Bridgman (1980) 24 SASR 278.

41 Also see the discussion above.

42 See generally Mueller and Kirkpatrick Federal Evidence 579-580.

43 See Mueller and Kirkpatrick Federal Evidence 581.

${ }^{44} R v$ White supra par 66.
} 
charged with murder and throughout the trial the identity of the shooter was an issue, but at the trial's end, the accused effectively admitted to culpable homicide, and the only issue that remained was whether the accused had the necessary intent for murder.

The prosecution argued that the conduct of the accused immediately after the gunshot went off was not reconcilable with the accused's claim that the gun was fired accidentally. They argued that the accused's lack of hesitation prior to fleeing pointed towards dolus rather than culpa. The majority agreed and pointed out that: ${ }^{45}$

"As a matter of logic and human experience, one would expect an ordinary person to present some physical manifestation, such as hesitation, at a gun in their hand accidentally discharging into someone's chest, thereby killing them. It was open to the jury to infer that a failure to react in this way was incongruous with the theory, advanced by the defence, that the gun went off by accident as the two men struggled with each other. To use the language of Arcangioli and White (1998), lack of hesitation was not 'equally consistent with' or 'equally explained by' accidentally as opposed to intentionally shooting the victim. It is less consistent with accident. Thus, the evidence that Mr. White did not hesitate when the gun was fired in response to this unexpected and calamitous turn of events supports an inference that he deliberately pulled the trigger."

Rothstein $\mathrm{J}$, on behalf of the majority, also considered the following two questions: Firstly, would the accused have been equally likely to flee the scene whether he was guilty of murder or of culpable homicide and, secondly, would the accused have been equally likely to hesitate before fleeing had he shot the victim intentionally or accidentally? The judge is of the opinion that these two questions raise distinct sets of considerations. On the one hand, nothing suggests that a person who has committed culpable homicide would be more likely to stay at the scene of a crime than one who has committed murder. In both cases they may flee for a number of reasons, such as to avoid arrest, to restrict evidence of that person's connection with the crime, or to buy time. ${ }^{46}$ On the other hand, however, logic and human experience suggest that people are more likely to hesitate, before continuing with their actions, when they have done something accidentally than when they have done it on purpose. The majority was therefore of the opinion that a lack of hesitation prior to flight is less consistent with shooting and killing someone accidentally than it is with doing so intentionally. ${ }^{47}$

Although the majority in $R v$ White accepted that a lack of hesitation prior to fleeing could point towards culpability, it is submitted that the dissenting view on the matter makes more sense. It is agreed with Binnie $\mathrm{J}$, writing for the dissent, ${ }^{48}$ that immediate flight without hesitation does not point only towards murderous intent. It is therefore not the only reasonable inference that can be drawn and fleeing without hesitation can be consistent with both culpable homicide and murder. Binnie $\mathrm{J}$ points out that because the accused's lack of hesitation and instantaneous flight are equally explained by the consciousness of more than one offence, the conduct has no

$45 \quad R \vee$ White supra par 67

$46 \quad R v$ White supra par 69.

${ }^{47} \quad R v$ White supra par 70; and see also par 79.

$48 \quad R v$ White supra par 154. 
probative value in relation to intent. It is further impossible to presuppose some sort of "normal" reaction in the circumstances of an accident. Someone's reaction in such a situation is entirely subjective and open to interpretation. ${ }^{49}$

Although evidence that the accused concealed, destroyed or tampered with evidence should be grouped together with evidence of lying and evidence that the accused intimidated possible witnesses under the broader category of post-offence conduct that aims to conceal the truth, it is mentioned here as a further example of an instance where evidence of postoffence conduct may have probative value as far as one fact in issue is concerned, but irrelevant as far as another is concerned. ${ }^{50}$ The Canadian Supreme Court case of $R v$ Jacquard ${ }^{51}$ provides an example of this situation. In this case the accused was charged with murder in connection with the killing of his stepfather and with attempted murder for the shooting of his stepfather's companion. During the trial the defence alleged that the accused was not criminally responsible because at the time of the shooting he was suffering from a mental disorder. They further alleged that the accused lacked the required intent for murder. Evidence at trial showed that the accused had hidden the murder weapon which, when found by the police, was free of fingerprints. The court found, per Lamer $\mathrm{CJ}$, that with respect to the intent to murder, that a "no probative value" instruction was necessary to be given to the jury in order to avoid the risk of an impermissible inference. ${ }^{52} \mathrm{He}$ did, however, consider the same post-offence conduct evidence relevant to an assessment of the accused's defence that he was suffering from a mental disorder. He pointed out that the alleged attempt to hide the murder weapon and destroy evidence was relevant circumstantial evidence to consider in evaluating the appellant's defence of being not criminally responsible. ${ }^{53}$ Although possible inferences can be

49 See $R v$ White supra par 188. Stewart "Towards a Principled Approach to Consciousness of Guilt: A Comment on White and Côté" 199943 Crim LQ 1727 remarks: "The natural response of the accused in this situation is to be overwhelmed by the fact of the killing rather than to think of the possibility of asserting a justification; even if the accused is aware that a claim of self-defence might arise, he or she is likely to think, 'l've just killed someone - l'm really in trouble now', and so to attempt to conceal involvement. In short, it is submitted that in many cases, post-offence conduct will have very little probative value on the issue whether a homicide is justified or unjustified."

50 In any event, the same general principles should apply when considering the admissibility of the various kinds of post-offence conduct evidence that could possibly be indicative of guilt.

51 [1997] 1 SCR 314.

$52 R$ V Jacquard supra par 49-50.

53 See also $R$ v Ménard [1998] 2 SCR 109. In this murder case the evidence against the accused was largely circumstantial. The sole issue at the trial was identity. The evidence of the post-offence conduct included false statements made to the police by the accused after the murder, evidence that he tried to dispose of the victim's bloodstained car and his own bloodstained clothing and that he attempted to flee from the area where he concealed the evidence. The accused argued that he acted solely out of fear that he would be linked to the stolen property and denied any involvement in the murder. His post-offence conduct seemed totally disproportionate to an alleged concern about stolen property and was therefore relevant. In $R v$ Rice (1996) 85 A Crim R 187 the accused was charged with murder, and in the alternative, the culpable homicide of his girlfriend. The deceased had disappeared after having spent a weekend with the accused. Except for telling a number of lies, the accused had also hidden the deceased body. The body was eventually found in a 44-gallon drum which had been left by the accused on a property belonging to an acquaintance. It was possible to conclude from this post-offence evidence that the accused had caused the death of the deceased through some wrongful act, but how could this evidence show that his act 
made where an accused destroys or conceals evidence, problems arise where the accused is successful in his attempt to conceal or destroy evidence. $^{54}$ If it cannot be ascertained what that evidence was it would seem to be impossible to make any inference as far as the guilt of the accused is concerned. ${ }^{55}$

\section{4 \\ EVIDENCE THAT THE ACCUSED LIED DURING THE INVESTIGATION}

It is extremely difficult to draw any inference about guilt from the fact that the accused lied during the investigation of the crime.$^{56}$ Lies can generally be used to discredit the accused's testimony but not to infer guilt. " In this regard a distinction can be drawn between "credibility lies" and "probative lies" ${ }^{58}$ In Zoneff $v R^{59}$ Kirby J explains the difference:

"The former are said to be those which, according to their content, affect the credibility of the accused's evidence and thus the weight which the jury may give to other testimony of the accused. In this sense, a conclusion that the accused has lied upon one matter, even peripheral to the offence charged, may make the jury scrutinise with more care (perhaps scepticism) other testimony given by the accused. It might, in this way, contribute indirectly to the rejection of the accused's version of critical events and the acceptance of

was performed with the mens rea for murder as opposed to culpable homicide? The lies and the concealment of the body were equally consistent with the accused having caused the death of the deceased in circumstances which would amount only to a charge of culpable homicide.

54 See generally Palmer 199721 Melbourne University LR 123 et seq.

55 For a further example of how post-offence conduct evidence may have probative value as far as one aspect of a case is concerned, but irrelevant as far as another is concerned, see the Canadian Supreme Court case of $R v$ Jaw [2009] 3 SCR 26.

56 In the South Australian case of Harris $v R(1990) 55$ SASR 321393 King CJ states in this regard that the "endeavour to improve their position by falsehood is far too common to enable an inference to be drawn with confidence, in any but the rarest of cases, that lies proceed from a consciousness of guilt". Evidence of lies can be grouped together with evidence that the accused intimidated witnesses and evidence that the accused concealed or destroyed evidence under the broader category of evidence that attempts to conceal the truth. Because the same basic principles should apply in deciding the probative value of such evidence, only post-offence conduct evidence of lies is discussed here.

57 The accused's lies could also be used to corroborate testimony by a witness - see the discussion below.

58 See Mathias "Lies Direction" 19959 NZLJ 307. In R v Toia [1982] 1 NZLR 555 CA 559 it is pointed out that there are two main ways in which lies by an accused may be important. Cooke $\mathrm{J}$ states on behalf of the New Zealand Court of Appeal: "First, occasionally they are capable of adding something to the Crown case, whether as corroboration or simply as strengthening evidence. But, as pointed out by this Court in $R v$ Collings [1976] 2 NZLR 104 ... most lies are not in that category. For example a false denial of being at the scene of the crime often does nothing to help prove that the accused committed the crime; he may simply want to avert unjust suspicion. It is only when a lie is more consistent with guilt than with innocence, as when it suggests that the accused cannot give an innocent explanation, that it can add anything to the case against him. ... Secondly, and more commonly, proved lies by an accused, whether in evidence or in statements out of Court, may be relevant to credibility. This is no more than a matter of common sense. They may help the jury to decide whether the evidence for the prosecution should be preferred to an account put forward by the accused." Also see R v Oakes [1995] 2 NZLR 673 684. For purposes of placing the main two types of lies into perspective it is also possible to identify a third type of lie, namely irrelevant lies. In this instance lies are told but they could reasonably be said to have been told for a purpose other than to conceal guilt - see Mathias 19959 NZLJ 307-310.

59 [2000] 200 CLR 234258. 
that propounded by the prosecution. Probative lies, on the other hand, are those 'which naturally indicate guilt ... a hard test to satisfy' ... This is a 'hard test' precisely because it is rare that a lie about a particular matter will be so crucial as, of itself, if proved, to establish directly guilt beyond reasonable doubt of a criminal offense.

It is crucial to understand the above difference. The absence of an apparent innocent explanation for the telling of a lie (going towards credibility) falls far short of the inability of the accused to give an innocent explanation for the lie (going towards probative value). ${ }^{61} \mathrm{~A}$ lie could, for example, directly establish guilt beyond a reasonable doubt where it relates to an object indisputably linked to the offence. In Zoneff $v R^{62}$ Kirby $\mathrm{J}$ refers to the example of a handkerchief with bloodstains proved by DNA evidence to be that of a victim but falsely attributed by the accused to be a nosebleed. In such a case it is said that the lie is direct evidence of guilt because the accused tells the lie knowing that telling the truth would necessarily, and without more, establish guilt of the offence charged. It has, however, been pointed out ${ }^{63}$ that "probative lies" may prove nothing more than that the accused had some connection with the crime, but a connection that is far from inadequate to demonstrate guilt of "the crime alleged, in manner and form alleged". ${ }^{64}$ In the case of the blood-stained handkerchief it might, for example, have been handed to the accused by a family member or lover whom he or she wished to protect.

There are many reasons why suspects lie. A suspect might, for example, lie not to hide his or her involvement in the crime under investigation, but to hide his or her involvement in another crime or to protect someone else who is in actual fact involved in the crime under investigation. Other suspects simply lie out of a sense of panic or to avoid the inconvenience of being involved in a criminal investigation. One can say that lying occurs to ensure that the truth does not emerge. But at the same time one can say that lying takes place out of a fear that the truth will not be known. ${ }^{65}$ It is further wellknown that accused persons often lie to enhance a weak but true cause. ${ }^{66}$

60 In the case of "credibility lies" this does not necessarily mean that the whole of the accused's evidence must be rejected. Mathias 19959 NZLJ 308 points out: "A lie may (indeed will) be relevant to credibility yet it may have no weight on the question of whether another piece of the accused's evidence is credible."

61 The New Zealand case of $R v$ Vallance [1955] NZLR 811 is an example of such a situation. In this case the accused was charged with indecent assault of a boy and the evidence of the boy required corroboration. The accused lied by saying that he always took the boy with him as the boy knew where the key was kept. Because there was other evidence that the accused knew where the key was kept, the jury was entitled to infer that he could only have made up this story since there was no other innocent explanation.

62 Supra 258.

63 See, eg, the remarks made by Windeyer $\mathrm{J}$ in Woon $v R$ supra $541-542$.

64 Woon v $R$ supra 542.

65 Palmer 199721 Melbourne University LR 121 refers to the following example by Sir Edward Coke "The Uncle's case" in Wigmore The Science of Judicial Proof (1937) 157: An uncle was suspected of having murdered his niece and was ordered by the court to produce the child. Unable to do so, he took along another child who resembled her. This fact was, however, discovered and he was found guilty of murder and hanged. Several years later the niece reappeared.

66 In Harris v $R$ supra 323 King CJ remarks: "The circumstances in which lies told after an accused becomes aware that he is or might be under suspicion in connection with the crime can amount to positive evidence of the commission of the crime must be rare. The tendency 
If lying is to be used as independent evidence of guilt, certain conditions will have to be met and alternative explanations for lying will have to be considered. In $R v$ Lucas $^{67}$ the English Court of Appeals stated that:

"To be capable of amounting to corroboration the lie told out of court must first of all be deliberate. Secondly it must relate to a material issue. Thirdly the motive for the lie must be a realisation of guilt and a fear of the truth. The jury should in appropriate cases be reminded that people sometimes lie, for example, in an attempt to bolster up a just cause, or out of shame or out of a wish to conceal disgraceful behaviour from their family. Fourthly the statement must be clearly shown to be a lie by evidence other than that ... to be corroborated."

Although stated in terms of corroboration, these principles should also apply as far as determining the guilt of the accused is concerned. ${ }^{69}$ It can be said that a lie must "amount to conduct which is inconsistent with innocence" 70 before it will have any probative value as far as the guilt of the accused is concerned. In $S \vee M$ Mtsweni $^{71}$ Smalberger AJA pointed out that care should be taken not to give undue weight to lies by the accused when it

of persons under suspicion to wish to distance themselves from the persons or events connected with the alleged crimes and to endeavour to improve their position by falsehood is far too common to enable an inference to be drawn with confidence in any but the rarest of cases, that lies proceed from a consciousness of guilt." About the Australian approach, see generally Ligertwood and Edmond Australian Evidence: A Principled Approach to the Common Law and the Uniform Acts 5ed (2010) par 4.84. A similar approach is followed in New Zealand - see the New Zealand Court of Appeal's decision in $R v$ Marshall [2004] 1 NZLR 793.

67 [1981] 1 QB 720724.

68 In Edwards v R (1993) 178 CLR 193199 Brennan J points out, in a minority judgment of the High Court of Australia, that there is some inherent circularity in the third of the stated tests. He notes: "If the jury must be satisfied that the motive for the lie is a realization of guilt and a fear of the truth, the jury must be satisfied that there is guilt to be realized before it decides whether to treat the supposed lie as corroboration of other inculpatory evidence. If the jury is satisfied of the accused's guilt, it would be unnecessary to consider whether his evidence is corroborative of evidence tending to prove his guilt. ... The relevant inference is not that the accused realized his guilt but that, in making his statement, he was unable to account innocently for the evidence that has been given against him." For the position in England consult Tapper Cross \& Tapper on Evidence 11ed (2010) 286.

69 See generally, Heydon "Can Lies Corroborate?" 197389 Law Q Rev 552.

70 In Edwards v R supra 209 the majority of the High Court of Australia notes: "It is only when the accused is telling a lie because he perceives that the truth is inconsistent with his innocence that the telling of the lie may constitute evidence against him. In other words, in telling the lie the accused may be acting as if he were guilty. It must be a lie which an innocent person would not tell. That is why the lie must be deliberate. Telling an untruth inadvertently cannot be indicative of guilt. And the lie must relate to a material issue because the telling of it must be explicable only on the basis that the truth would implicate the accused in the offence with which he is charged. It must be for that reason that he tells the lie. To say that the lie must spring from a realization of guilt or consciousness of guilt is really another way of saying the same thing. It is to say that the accused must be lying because he is conscious that "if he tells the truth, the truth will convict him." Cf the remarks made by Hunt CJ in the New South Wales Court of Criminal Appeal case of $R v T(1997) 92$ A Crim R 390 stating (393): "For a lie to amount to an admission of guilt the only reasonable inference from the circumstances in which it was told must be that the accused lied because he knew that, if he told the truth, he would be found guilty."

711985 (1) SA 590 (A) 593I-594D. The court notes (594E-F): "Voordat 'n skuldigbevinding aan moord kan geskied moet daar bewese feite wees wat by wyse van afleiding die appellant aan die dood van die oorledene koppel. By ontstentenis daarvan bestaan daar nie ' $n$ prima facie saak teen die appellant nie, en kan sy leuenagtige getuienis net soos in die geval waar hy nie getuig nie, nie die leemtes in die Staat se saak aanvul en 'n gevolgtrekking van skuld regverdig nie." 
comes to inferences to be drawn from such evidence and when determining guilt. The weight to be given to such evidence should coincide with the circumstances of each case. The following considerations apply when evaluating false evidence by the accused: (a) the nature, extent and material significance of the lies told and if they necessarily point to a realization of guilt; (b) the accused's age, level of development, cultural and social background and standing in so far as they can give an explanation for the lies; (c) possible reasons why people turn to lies; (d) the tendency that some people have to deny the truth because they are afraid they are going to be implicated in a crime, or because they are afraid that admission of their involvement in an incident or crime, however trivial, contains the danger of inference of participation and guilt that is disproportional to the truth. ${ }^{72}$

\section{CONCLUSION}

Most post-offence conduct evidence will simply become part of the record as "an unremarkable part of the narrative". ${ }^{3}$ Where post-offence conduct evidence is an indispensable link in the chain of proving guilt, any inference to be drawn from such evidence must be established beyond a reasonable doubt. ${ }^{74}$ If all other reasonable inferences are not excluded, then there must be doubt whether the inference sought to be drawn is correct. Whether all reasonable inferences have been excluded will mostly be determined by the type of post-offence conduct in question. It will not be enough to draw an inference from facts that were not, themselves, proved beyond a reasonable doubt. The cumulative effect of a number of facts, proved on reasonable grounds, will therefore not suffice.

72 This approach was confirmed in $S v$ Lujaba 1987 (1) SA 226 (A) 235I-236F. See also $S v$ Campos 2002 (1) SACR 233 (SCA); and S v Burger 2010 (2) SACR 1 (SCA) par 30. Zeffertt, Paizes and Skeen The South African Law of Evidence point out, however, that these principles have not always been adhered to (see the cases of $S v$ Safatsa 1988 (1) SA 868 (A); and S v Skweyiya 1984 (4) SA $712(\mathrm{~A})$ ). For an older case where these principles were correctly applied, see $S v$ Mnguni 1966 (3) SA 776 (T).

$73 \quad R v$ White supra par 140.

74 Cf Edward $v R$ supra 203-204. Brennan J gives perspective in this regard after referring to remarks made in Chamberlain v $R$ (1984) 153 CLR 521 559; and Shepherd v $R(1990) 170$ CLR 573,583 and 584 by pointing out: "Adopting his Honour's nomenclature, Chamberlain [No.2] requires that no element of the offence be inferred adversely to an accused unless the intermediate facts from which the inference is drawn be proved beyond reasonable doubt. But, as Shepherd holds, Chamberlain [No. 2] imposed no requirement that the jury accept beyond reasonable doubt every piece of inculpatory evidence relevant to the existence of an intermediate fact. ... The pieces of evidence are 'strands in a cable' tending to establish a material fact, but intermediate facts established by evidence are links in the chain of proof of the fact to be inferred. ... The standard of proof applies to links; it says nothing about the strands. ... If the ultimate facts - those which constitute the elements of the offence charged - are to be inferred from intermediate facts, the standard governs both the finding of the intermediate facts and the drawing of the inference from them." 